\title{
CELSR2 Gene
}

National Cancer Institute

\section{Source}

National Cancer Institute. CELSR2 Gene. NCI Thesaurus. Code C140181.

This gene plays a role in cell-cell signaling during the development of the nervous system. 